\title{
Viral Democracy Indonesian Social Media Discourses on MD3 Law
}

\author{
Andriko Sandria and Rizaldi Yasid Purnama Putra \\ International Relations Department,Universitas Sebelas Maret, Jl. Ir.Sutami No.36A, Surakarta, Indonesia \\ andrikosandria.ma@staff.uns.ac.id, rizaldiyap@student.uns.ac.id
}

Keywords: $\quad$ MD3 Law, democracy, discourses, social media, viral, Indonesia.

Abstract: $\quad$ The House of Representatives (DPR) of Indonesia issued Law no. 2 of 2018 as a renewal of Law no. 27 of 2009 which regulates the People's Consultative Assembly, the House of Representatives, the Regional Representatives Council, and the Regional Representative Council (MD3). The main purpose of this paper is to analyze the discourses that occurred during the ratification of MD3 Law on Twitter. The discussion which focused on democracy value that distributed in society as internet user will contribute to advance discourses about democratization in Indonesia. Some captured viral contents were collected from several key actors who actively posted their opinion about the MD3 law. Selected comments were chosen by proportionated sampling method with some criteria such as lengths, contents, and dictions. This paper conducted intext discourse analysis on internet society conversation on viral content about MD3 law on the internet which focused on identifying and characterizing discourse. The results showed that the Indonesian President, politicians, and social media users were actively involved in the conversation about MD3 Law. The discourses about the declining of democracy through MD3 law indicated that the democratization process in society was tested and showcased by doing proactive actions within the value of democracy.

\section{INTRODUCTION}

The House of Representatives (DPR) of Indonesia issued Law no. 17 of 2014 as the renewal of Law no. 27 of 2009 on July 8, 2014. This law regulates the People's Consultative Assembly, the House of Representatives, the Regional Representatives Council, and the Regional Representative Council (MD3). After being passed a day before the Presidential Election, the draft was revised on July 10, 2014, which arises public questions and was warmed up in social media with the revisions the law (Kosandi, 2015). Seven lawsuits were reported to the Constitutional Court for conducting a judicial review of the MD3 Act. As for several articles being sued are sections 84, 97, 104, 109, 115, 121, 152, and 166 (Kosandi, 2015). On December 5, 2014, the Parliament conducted a limited revision of MD3 Law.

On February 12, 2018, the House yet again revised the second act of MD3 and renamed it as Law no. 2 of 2018. This second revision led to a wave of great rejection from the community. The passing of this second revision raises the stigma that the House is against criticism (Saraswati, 2018). In this second revision, the House of Representatives is also entitled to take a firm stance when there are parties who undermine the honor of the House of Representatives. One of the most highlighted points of the second revision of 2018 is the $122 \mathrm{~K}$ article, namely the emergence of the right for the House to prosecute anyone who criticizes the House.

The wave of rejection that occurred in the community was strongly related to the revised adoption of the MD3 Law. Much criticism, input to the scold addressed to the members of the House of Representatives is related to the Revision of this MD3 Act in social media, such as Twitter. As time passes, social media is one of a place to voice opinions and criticism. The emergence of various criticisms and inputs to the government proves that there is a close relationship between social media and freedom of expression. This relationship becomes another manifestation of the implementation of democracy in social media. This can happen because social media facilitates the fulfilment of the right of each individual to express their opinions without being hampered by external parties (Tully, 2014). 


\section{METHODS}

Social media transforms the democratization process in society. Within this opportunities and accessibilities, society uses communication technology and network to deliberate what can be seen and evaluated from the government (Tully, 2014). Democratization through social media was successfully affecting the society in authoritarian states which can be seen on what happened during Arab Spring in the Middle East (Tully, 2014). Tully's explanations about the transformation of democracy through social media relatively can explain the discourses that occur about MD3 Law in Indonesia.

Norman Fairclough explained that discourses are ways of constituting the values and norms of the world. Discourses can be differently represented which caused by individual subjectivity. This subjectivity consists of processes, relations, and structure of the material world, thoughts, feeling, belief, and social world (Fairclough, 2003). This paper conducts text discourse analysis on internet society conversation in viral content about MD3 law on the internet.

\subsection{Data collecting}

The main data used in this paper analysis is obtained from the digital twitter track record that is uploaded by several political figures. These elected actors are those who actively contend on MD3 legislation. The elected actors in this paper are Fahri Hamzah, Joko Widodo, and Tsamara Amany. Selected comments were chosen by proportionated sampling method with some criteria such as lengths, contents, and dictions. The comments were analyzed using text discourse analysis.

Supporting data in this paper is obtained through various resources obtained from several sources such as books, journal articles, articles, news, and publications that can be accessed on the internet media.

\subsection{Text discourse analysis}

Discourse analysis in this paper focuses on identifying and characterizing the discourse. Fairclough explained that in the identifying process, "it is important to determine (a) representing some particular part of the world, and (b) representing it from a particular perspective (Fairclough, 2003)". The discourses that would be analyzed in this paper focus on the conversation between people about MD3
Law in social media which became viral due to the issues.

\section{RESULTS AND DISCUSSIONS}

Some captured viral contents were collected from several key actors who actively posted their opinion about MD3 law. The pictures were paired due to the main tweet from the actors is followed by comments from other users.

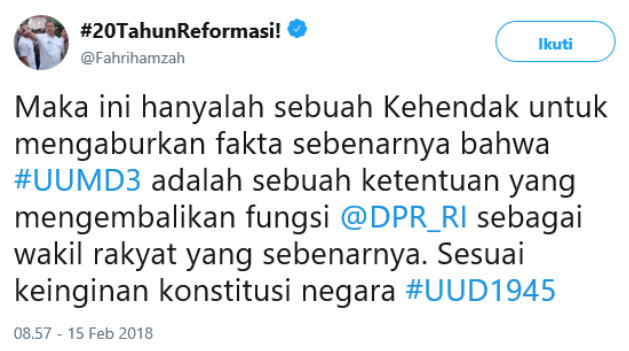

Figure 1: Fahri Hamzah's tweet on twitter.

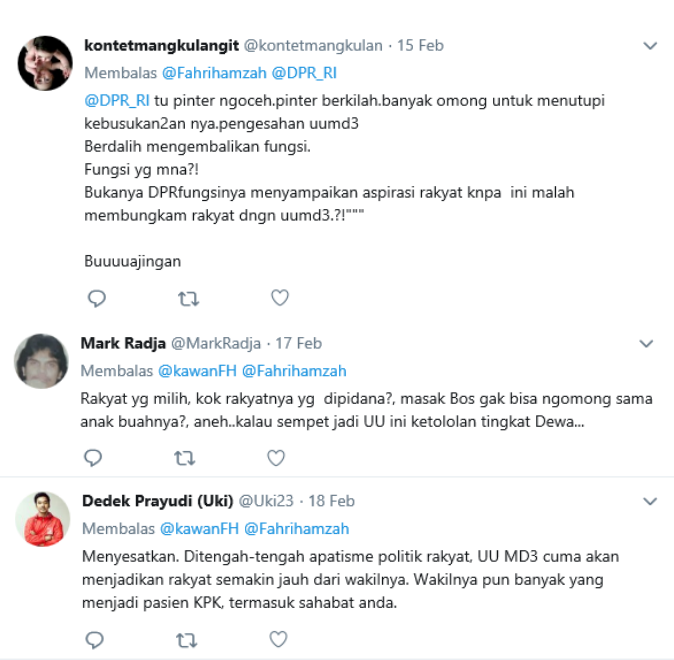

Figure 2: Comments on Fahri Hamzah's tweet.

Fahri Hamzah's tweet stated that the main purpose of MD 3 Law was getting back the power of the House of Representative as a component of Trias Politica based on the Indonesian constitution (see figure 1). The language of "mengaburkan fakta" was chosen to claim that the House of Representative did a great job in producing a law to protect the institution. This word refers to his clarification that the facts spreading in the media are not true. Media had just blurred the real purpose of MD 3 Law. The whole contents of his tweet also invited Indonesian 
internet user to analyze the real purpose of this law and referring to the constitution's purpose.

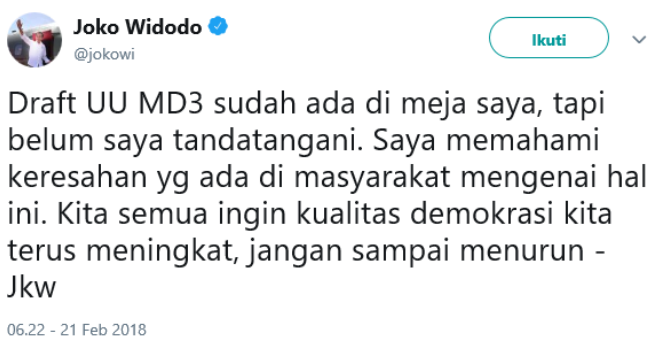

Figure 3: Joko Widodo's tweet on twitter.

In Jokowi's tweet, he stated that he has received the MD3 draft law but has not yet signed it because he understood the political unrest in the community related to the law (see Figure 3 ). The step taken by Joko Widodo is a manifestation of keeping the propeople that has been attached to him. This image began to emerge when Joko Widodo is running for the Presidential Candidate during the 2014 Election. Many actions made by him led to the accepting stance from pro-people such as doing 'blusukan', distributing aid/subsidy to the poor, and so on. This is one helpful factor to understand the steps taken by him on addressing the MD3 Law. In the last sentence of his tweet, Jokowi conveyed that his attempt to improve democracy has not lowered. This can be seen as a direct blow to the MD3 Act which considered as a cause to weaken the democracy.

Tsamara Amany's was using short, simple statement for her tweet before MD3 law officially ratified on March 2018. The phrase "menolak dibungkam" (see Figure 5) is an explicit verbal language that is used to reject particular contents stated in the MD3 law about the freedom to express arguments and opinions. Historically, the freedom of expression was the main issue that was demanded by society during the 1998 reformation. In her tweet, Tsamara Amany also used the word "Kamu?" with a question's mark in the end. This word indicated her purpose on inviting the society also to state their opinion about MD3 Law. There is a belief that Indonesian society has a good understanding and interpretation of democracy. She indirectly asked the society to participate actively in the discourses that occurred about weakening democracy value related to MD3 Law.

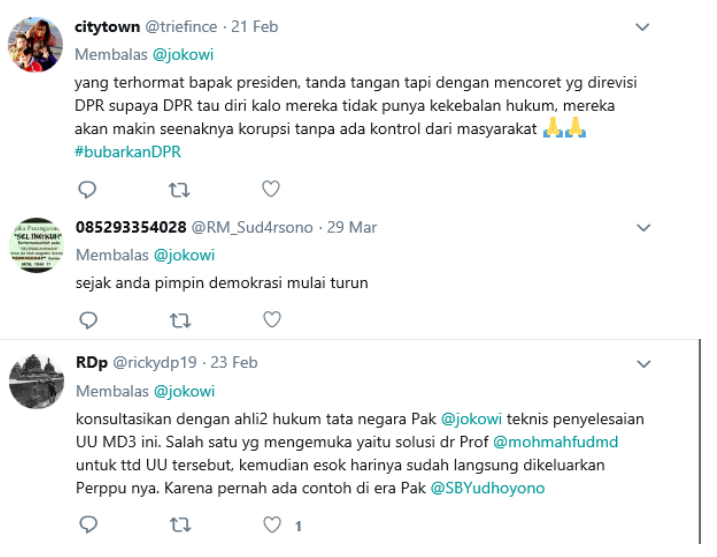

Figure 4: Comments on Joko Widodo's tweet.

There are several forms of comments from social media users who tend to be rude and unfounded. The comments tend to strike weakly and have no strong arguments. For example, @contetmangkulan account delivered a series of sarcasm and insults (see Figure 2). Although there was a feedback at the end of his comments regarding the consistency of the House on representing the people, the statement from his account is considered impolite.

Same type of response was also shared by accounts namely@guesx1 and @markradja. Each of them uttered a comment that the people could "melempar" the House of Representatives into the bin and constitute a "ketololan tingkat dewa" if the Law was successfully passed (see Figure 2). From the two comments, it can be seen how the law angers the people. In fact, people do not hesitate to say inappropriate words in social media to attack and berate the House of Representative.

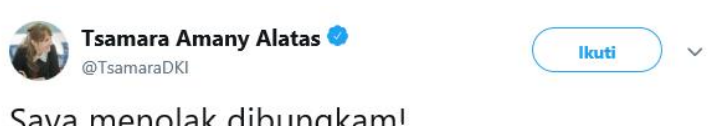

Saya menolak dibungkam!

Kamu?

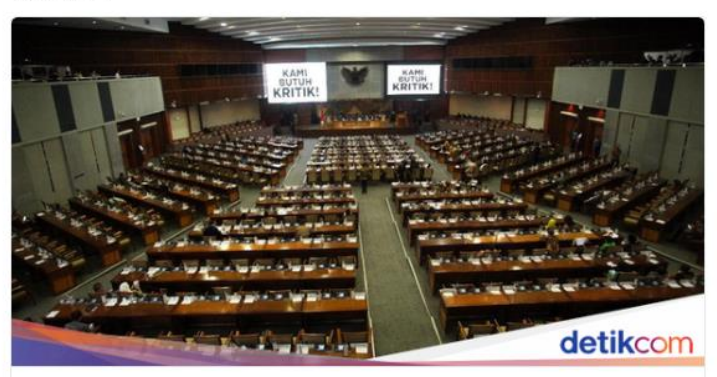

Pakar Hukum: UU MD3 Berlaku Hari Ini, Kritik DPR Bisa Dipidana

Pasal-pasal di UU MD3 yang dinilai kontroversi pun mau tak mau sudah bisa diterapkan. Termasuk pasal anti kritik DPR.

news.detik.com

Figure 5: Tsamara Amany's tweet on twitter. 


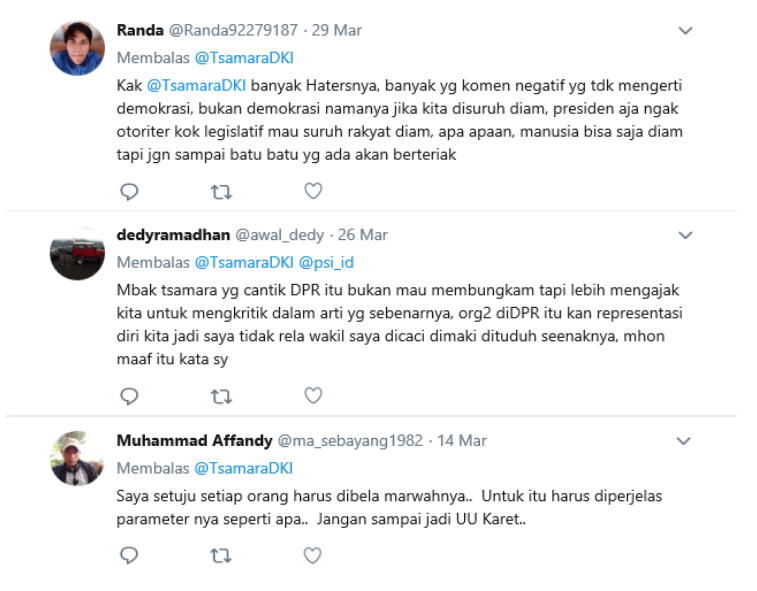

Figure 6: Comments on Tsamara Amany's tweet.

There are also some comments that bring disappointment to the MD3 Law. They are stated by twitter account@budywinoho,@uki23, @nurmila2891, and @ triefince who submit comments in a polite way with careful selections of words and dictions. As directed by the account @uki23, he wrote his comments related to the MD3 Law using polite and refined language, but still contain criticism to Fahri Hamzah and Parliament in the topics. Other examples such as those by @ triefince account, the owner is expressing his appeal regarding the MD3 Law not to be signed by Joko Widodo. The user expresses his request directly through the reply field of the Joko Widodo's tweet (see Figure 4). In his delivery, he uses polite language and does not include harsh and disrespectful words. Ultimately, this type of comment is more convenient to read and accepted.

Other type of comment can be found on @ rickydp19 account's statement towards President Joko Widodo's tweet regarding the MD3 Law. He delivered his comments using polite words, did not offend any party, and providing solutions related to the case of the issue. In his comments, he referred the President to signed and issued Perppu to tackle the MD3 law through the Constitutional Court (MK) chairman Mahfud MD to resolve the MD3 act (see Figure 4). This social media user also provides a historical overview of the strategy he is conveying. Although his comment was not necessarily responded directly by the government and president, he has given on a solid basis and provide a clear solution.

\section{CONCLUSIONS}

The discourses about the weakening of democracy through MD3 law indicated the democratization process in society was tested and showcased by doing proactive actions within the value of democracy. Though various languages/dictions were indicating that the participation in the election is going to decline in the discourses about MD3 Law, the value of democracy has already rooted and developed properly in Indonesian society.

\section{REFERENCES}

Fairclough, N. (2003) Analysing Discourse: Textual Analysis for Social Research. Routledge.

Kosandi, M. (2015) 'Kontestasi Politik dan Perimbangan Kekuasaan dalam Perumusan dan Implementasi UU MD3 2014', Jurnal Politik, 1(1). doi: 10.7454/jp.v1i1.8.

Saraswati, D. (2018) Sahkan UU MD3, DPR Disebut Antikritik dan Makin Tak Dipercaya. Available at: https://www.cnnindonesia.com/nasional/201802141451 21-32-276189/sahkan-uu-md3-dpr-disebut-antikritikdan-makin-tak-dipercaya (Accessed: 26 May 2018).

Tully, S. (2014) 'People You Might Know : Social Media in the Conflict between Law and Democracy', in Patmore, G. and Rubenstein, K. (eds) Law and Democracy. ANU Press, pp. 153-171. Available at: http://www.jstor.org/stable/j.ctt13wwvp7.12. 